\title{
FORUM
}

\section{Dark Clouds and Their Silver Linings: Exotic Generalist Predators in Augmentative Biological Control}

\author{
Patrick De ClercQ \\ Lab. Agrozoology, Dept. Crop Protection, Ghent University, Coupure Links 653, B-9000 \\ Ghent, Belgium, e-mail: patrick.declercq@rug.ac.be
}

Neotropical Entomology 31(2): 169-176 (2002)

Das Nuvens Escuras um Raio de Luz: Controle Biológico por Aumento da População de Predadores Generalistas Exóticos

RESUMO - Vários artrópodos predadores polífagos estão disponíveis para uso em controle biológico pelo aumento da população, com o objetivo de controlar ácaros e insetos-praga em ampla variedade de culturas. Muitos desses predadores não são nativos da área onde serão introduzidos. Neste artigo discutem-se os beneficios e os riscos do uso de predadores generalistas exóticos como agentes de biocontrole. $\mathrm{O}$ fato de os predadores polífagos serem criados facilmente em alimento não-natural e poderem ser usados contra diferentes espécies de pragas, faz com que eles se tornem atrativos para comercialização. Predadores polífagos ou fitófagos facultativos apresentam menor dificuldade em se manterem na presença de baixas populações das presas e podem ser introduzidos nas culturas antes que a praga-alvo esteja presente, evitando o crescimento de populações de pragas que possam causar danos econômicos. Por outro lado, espécies generalistas podem interferir com outras espécies benéficas na cultura e espécies facultativas podem, excepcionalmente, causar danos às culturas. $\mathrm{O}$ uso de inimigos naturais não-nativos pode envolver riscos ambientais. Procedimentos para a avaliação de riscos, enfocando principalmente a amplitude de hospedeiros, têm sido implementados em um número crescente de países. A avaliação da especificidade hospedeira, entretanto, deve ser conduzida em condições reais. Em adição, a adequabilidade do clima, a habilidade de dispersão de um predador importado e a presença de seus inimigos naturais na área de introdução são fatores importantes quando se avaliam os riscos ambientais. As normas reguladoras são essenciais mas não devem dificultar a implementação do controle biológico como alternativa ao controle químico de pragas.

PALAVRAS-CHAVE: Controle biológico, predadores, polifagia, efeitos em insetos não-alvo.

ABSTRACT - Several polyphagous arthropod predators are commercially available for augmentative biological control targeting mite and insect pests in a variety of cropping systems. A number of these predators are not native to the area of release. The current paper discusses benefits and risks of using exotic generalist predators as biocontrol agents. The fact that polyphagous predators are easily reared on unnatural foods and can be used against different pest species makes them attractive for commercialization. Polyphagous or facultatively phytophagous predators have less difficulty in maintaining their populations at low prey densities and can sometimes be introduced in the crop before the target pest is present, thus preventing the buildup of pest populations before economic damage is done. On the other hand, generalists may interfere with the action of other beneficials in the crop, and facultative plant feeding by predatory arthropods exceptionally causes crop damage. The use of nonnative natural enemies may entail environmental risks. In a growing number of countries, risk assessment procedures are being implemented that are largely focused on host range testing. It is emphasized, however, that the experimental evaluation of host specificity should be done under realistic conditions. Furthermore, climatic matching and dispersal ability of an imported predator and the presence of its natural enemies in the area of introduction are important factors to be considered when assessing environmental risks. Regulation is essential but should not hamper the implementation of biological control as an alternative to chemical pest control.

KEY WORDS: Biological control, augmentation, predators, polyphagy, non-target effects. 
As policy makers worldwide increasingly emphasize the need for integrated agricultural production, there has been a continually growing demand for biological control agents to protect crops against pests, diseases, and weeds. In augmentative biological control, mass-reared natural enemies are being released with the purpose of providing pest suppression in the short term (by inundation, with an immediate effect by the released individuals) or in the longer term (by seasonal inoculation, with an effect over a number of generations through in-field reproduction by the released individuals) (van Lenteren \& Woets 1988, Van Driesche \& Bellows 1996). Presently, over 150 species of arthropods are commercially available worldwide for augmentation programs targeting a wide array of mite and insect pests (Anonymous 2001).

At least half of the species commercialized for biological control in European protected cultivation are exotic. This is related to the fact that most European countries impose on distributors of beneficials no restrictions regarding the importation and use of non-native species. In North America there appears to be a lower number of exotic species on the biocontrol market, because of more stringent regulations on the importation of nonindigenous organisms. However, the so-called "native" beneficials on the North American market include several non-native arthropods that have been introduced, intentionally or accidentally, in the more or less recent past and that are now considered to be established (e.g., the coccinellids Adalia bipunctata (L.), Harmonia axyridis (Pallas), Rhizobius lophanthae (Blaisdell), and Stethorus punctillum Weise). Also in South America several small businesses have been rearing and supplying natural enemies for augmentation purposes (e.g., in cotton production). However, the scattered market situation yields an unclear picture of the beneficials that are commercially available in the different countries of that continent.

In some cases, the use of non-native natural enemies may be required to enable successful control of exotic pests. Very often, however, globalization of the marketplace has sparked the demand for nonindigenous biocontrol agents. This demand may be inspired by (not necessarily scientific) reports of successful control in other parts of the world, but may also be catalyzed by the mere fact that a beneficial is commercially available elsewhere (where it may be indigenous) and is believed to have potential for the local market.

In augmentative biological control massive numbers of laboratory-produced natural enemies are typically released (100,000-300,000 per hectare) (van Lenteren 2001). The intensive use of exotic biological control agents in augmentation programs has led to growing environmental concerns. Non-native beneficials released in agricultural plots may invade and disrupt natural ecosystems (Howarth 1991, 2001). There is a general consensus that such risks may be more serious when generalists are employed (Lockwood et al. 2001). On the other hand, generalist natural enemies may have distinct assets for use in biological pest control. The current paper tries to balance benefits and risks of non-native generalist arthropod predators in augmentative biological control.

\section{Generalists and Specialists}

In this context, the question arises: What does one mean exactly when referring to a "generalist" or "polyphagous" predator? Torre-Bueno (1937) states that polyphagy means eating everything, i.e., the condition of being unspecialized as to food. According to Leftwich (1976), "polyphagous" refers to feeding on a variety of different foods or parasitizing a number of different hosts, but not completely omnivorous. Matthews \& Matthews (1978) specify that polyphagy indicates a condition of accepting a wide variety of foods, but showing decided preferences. Provided that we accept "generalist" (as opposed to "specialist") as a synonym of "polyphagous", a generalist predator has a wide host range, i.e., it will accept different species as prey, but may still display distinct preferences. But this definition is still equivocal, because what is "a wide host range"? Overall, arthropod predators are hardly ever monophagous, but they may attack a few or numerous species in their natural habitat. Some feed on different species within a genus or family (e.g., acarophagous cecidomyiids, some mite-, whitefly-, and coccid-eating coccinellids), whereas others may accept prey from different families (e.g., some chrysopids and coccinellids, many heteropteran predators). This situation is further complicated by the fact that many predatory arthropods are facultatively phytophagous, feeding in their larval and/or adult stages on plant sap (e.g., numerous heteropteran predators), pollen (e.g., some anthocorids, coccinellids, syrphids, phytoseiids), or other plant components. Albajes \& Alomar (1999) concluded that it may be more relevant to refer to the degree of polyphagy in predators rather than opposing polyphagy to monophagy. Symondson et al. (2002) presumed that because of physical, physiological, and behavioral restrictions, the majority of predators labelled generalists are in fact "stenophagous" to varying degrees; "stenophagy" refers to the condition of having a limited range of prey species (Gordh \& Headrick 2001).

There are different methods for determining whether a predator is more of a specialist or more of a generalist: making field observations of foraging predators, analyzing the gut contents of field-sampled predators, and performing laboratory feeding and preference tests (see Powell et al. 1996 for a review). However, all these methods have their shortcomings or practical drawbacks. Field observations are tedious and may be difficult in the case of minute or fastmoving arthropods. Disproportionate field sampling may lead to an underestimation of a predator's food range. Laboratory tests in small artificial arenas, on the other hand, may yield host ranges that are not ecologically meaningful. Moreover, laboratory experiments usually disregard interspecific interactions occurring in multispecies systems (Symondson et al. 2002). To get an accurate idea of a predator's feeding habits, a combination of methods is therefore recommended.

I will illustrate this issue with some examples from the pentatomid subfamily Asopinae. Members of Asopinae, also known as predatory stinkbugs or soldier bugs, are set apart from the other pentatomid subfamilies by the essentially predaceous feeding habits of nymphs (with the exception of 
first instars) and adults. In addition, they are often observed to feed on plants, a habit that provides them with moisture and perhaps some supplemental nutrients. A literature survey suggests that none of the Asopinae is truly host specific although there appears to be some degree of specialization in a number of species (De Clercq 2000). The spined soldier bug, Podisus maculiventris (Say) (Fig. 1) is probably the best known species of this group. It is being commercialized in North America and Europe mainly for biological control of the Colorado potato beetle in potatoes and of noctuid caterpillars in vegetables (De Clercq 2000, Anonymous 2001). McPherson (1980) listed over 90 species of insects as recorded prey for $P$. maculiventris. It is worth noting, however, that several of these records sprang from laboratory observations, so that they may not be ecologically significant. Field and laboratory observations indicate that the spined soldier bug has a particular preference for lepidopteran larvae. Nonetheless, the wide range of habitats occupied and of prey insects attacked by $P$. maculiventris suggests that this pentatomid is a fairly generalist predator. A similar conclusion can be drawn for the Neotropical species Podisus nigrispinus (Dallas), that has been released against defoliating caterpillars in agricultural and forest ecosystems in Brazil and other South American countries (De Clercq 2000). The two-spotted stinkbug, Perillus bioculatus (F.) (Fig. 2), on the other hand appears to be more of a specialist predator. It is believed to have potential as a biocontrol agent of the Colorado potato beetle but is not commercially available at present. Although Knight (1923) believed that $P$. bioculatus feeds almost exclusively on the Colorado potato beetle, in the laboratory this predator was observed to feed on insects from different orders; in the field, however, it is usually found in association with coleopterous insects, especially Chrysomelidae (see De Clercq 2000 for references). Specialization of P. bioculatus toward chrysomelid prey was confirmed by Saint-Cyr \& Cloutier (1996), who demonstrated a genetically inheritable

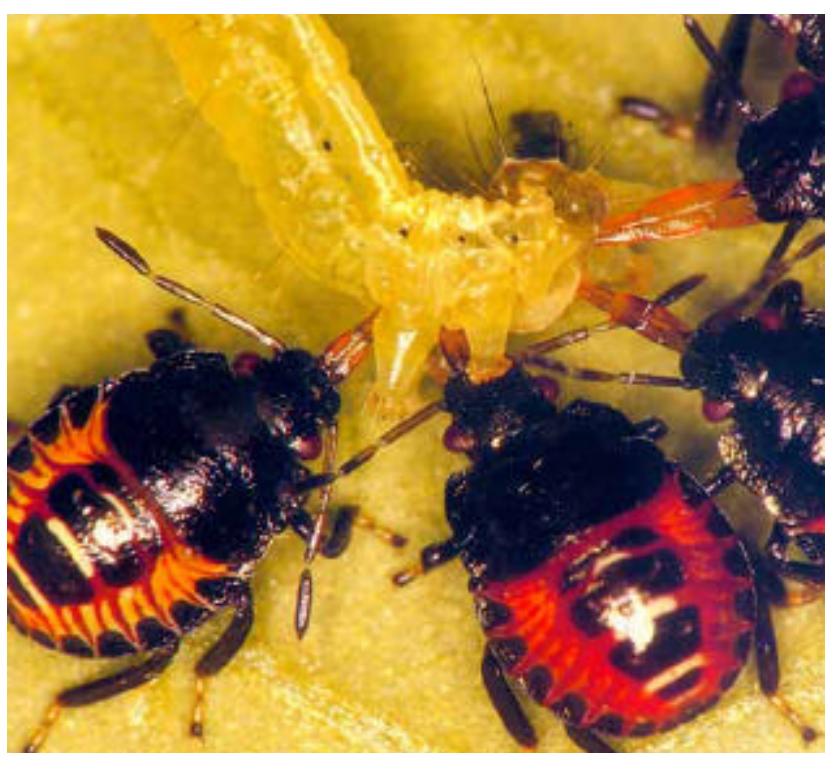

Figure 1. Nymphs of $P$. maculiventris attacking a Chrysodeixis chalcites (Esper) caterpillar (photo V. Vacante). as well as maternally reinforcible affinity toward the Colorado potato beetle. So, whereas some asopine bugs are generalist predators attacking a wide array of prey in a diversity of habitats, others appear to be more closely associated with a limited number of insects and occur in few habitats. In this respect, Schaefer (1996) hypothesized that there may be an evolutionary progression from drab asopines that feed rather generally to bright asopines preferring Chrysomelidae and, to a lesser extent, Coccinellidae.

\section{Potential of Generalist Predators for Biological Control}

Several authors have tried to list the attributes that make a natural enemy an effective biocontrol agent (e.g., Huffaker et al. 1976, van Lenteren \& Woets 1988, Wiedenmann \& Smith 1997, Albajes \& Alomar 1999). Population regulation theory, which has mainly evolved around classical biological control, assumes that the ability to achieve a low, stable pest equilibrium is the main feature of an efficient natural enemy. Because traits leading to stable equilibria (high degree of host specificity, high searching efficiency, aggregative response...) are more characteristic of parasitoids, this view has entailed a depreciation of the value of predators as biocontrol agents. However, some workers questioned the need for stability and argued that local extinctions could be compatible with effective biological control (e.g., Murdoch et al. 1985). Stable pest-enemy equilibria are less relevant for augmentative biological control programs, which are often deployed in temporally unstable and closed agroecosystems, like protected crops. Practice has shown that polyphagous predators can be highly effective in seasonal inoculative or inundative releases targeted against greenhouse pests (van Lenteren \& Woets 1988, Albajes \& Alomar 1999). A review of manipulative field studies in protected, annual and perennial crops showed that in about $75 \%$ of cases, generalist

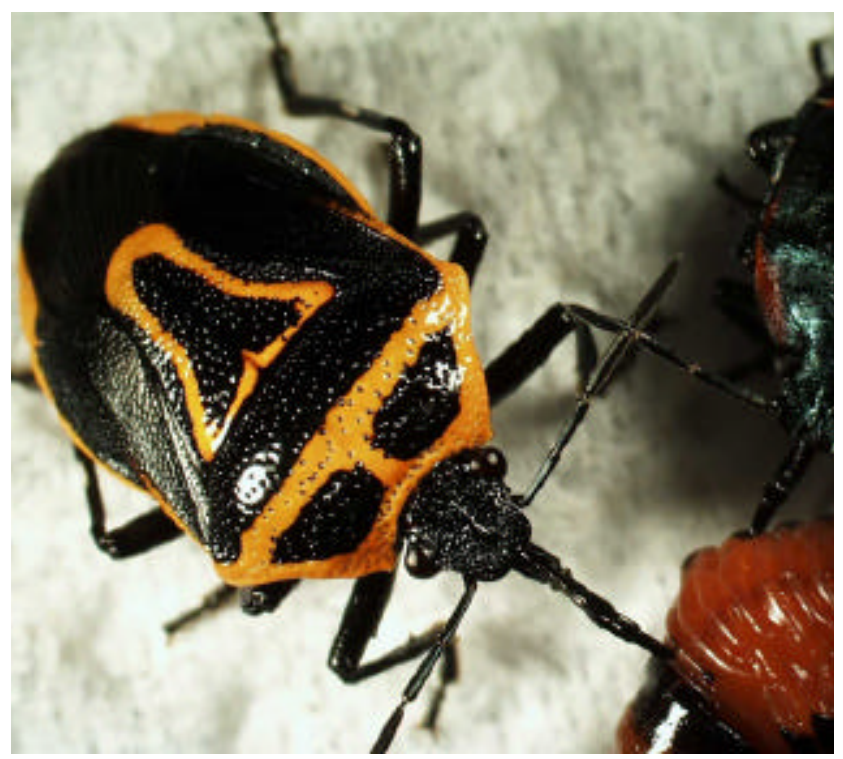

Figure 2. P. bioculatus feeding on a Colorado potato beetle larva (photo P. De Rop). 
predators reduced pest numbers significantly (Symondson et al. 2002).

The more important attributes that make a predatory arthropod suitable for use in augmentative biological control are briefly discussed below. Clearly, no one species combines all the attributes of the ideal natural enemy.

A predator to be used in augmentation programs should be able to quickly suppress the pest population. A high kill or growth rate, exceeding the intrinsic rate of increase of the pest, is evidently an important prerequisite. However, many workers have emphasized that a good searching capacity, particularly at low pest densities, is at least as important as a selection criterion. This widespread opinion has sparked the search for natural enemies that are able to use specific cues to locate their prey (e.g., kairomones, synomones) and display aggregative responses, traits that are often thought to be more characteristic of specialists than of generalists. However, it has been demonstrated that (what appears to be) randomly searching predators, which mainly rely on their high mobility, can be effective biocontrol agents. Moreover, also in several polyphagous species the use of chemical cues for prey location has been revealed. For instance, the highly polyphagous pentatomid P. maculiventris, long believed to search at random, has recently been found to use volatiles produced by damaged plants for prey detection (Dickens 1999). Further, adaptations to varying conditions of climate and food availability may be welcome attributes for biological control agents. Because generalists are usually less synchronized with their prey than specialists, generalists show better behavioral and physiological adaptations to prey scarcity and may thus be more successful in sustaining their populations at critical times (e.g., Legaspi \& Legaspi 1998).
Polyphagy and facultative phytophagy can be considered as adaptations of predators to infrequent food supplies. Nonspecific predators are less dependent on the population levels of one particular species. Their polyphagous nature enables them to feed on alternative prey in case a preferred prey species or prey type becomes scarce. Feeding on plants may also help in sustaining populations of a predator until prey becomes locally more abundant. Because polyphagous predators can use alternative food sources, they can be introduced in the crop before the target pest is present and thus prevent the buildup of pest populations before economic damage is done (e.g., preventive releases of pollen-eating anthocorids and phytoseiids in protected crops).

The traits that determine the potential of a predator for use in augmentative biological control programs are not only related to pest suppression, and there may be other arguments for selection of a natural enemy as a control agent. Cheap and reliable mass production yielding high-quality natural enemies is a prerequisite for cost-effective pest control (Leppla \& King 1997). The use of factitious foods [e.g., eggs of Sitotroga cerealella (Olivier) or Ephestia kuehniella Zeller] or artificial diets (Fig. 3) can enhance mechanization of rearing procedures and thus lower production costs. In many cases, generalist predators are more amenable to rearing on factitious or artificial foods than specialist predators, which has stimulated the adoption of generalists in commercial biological control. The fact that, like broad-spectrum pesticides, some polyphagous predators can be used against different pest species may also be an important asset for commercialization [e.g., Macrolophus caliginosus Wagner, Orius spp., P. maculiventris, Chrysoperla carnea (Stephens), Hippodamia convergens Guérin-Méneville, H. axyridis].

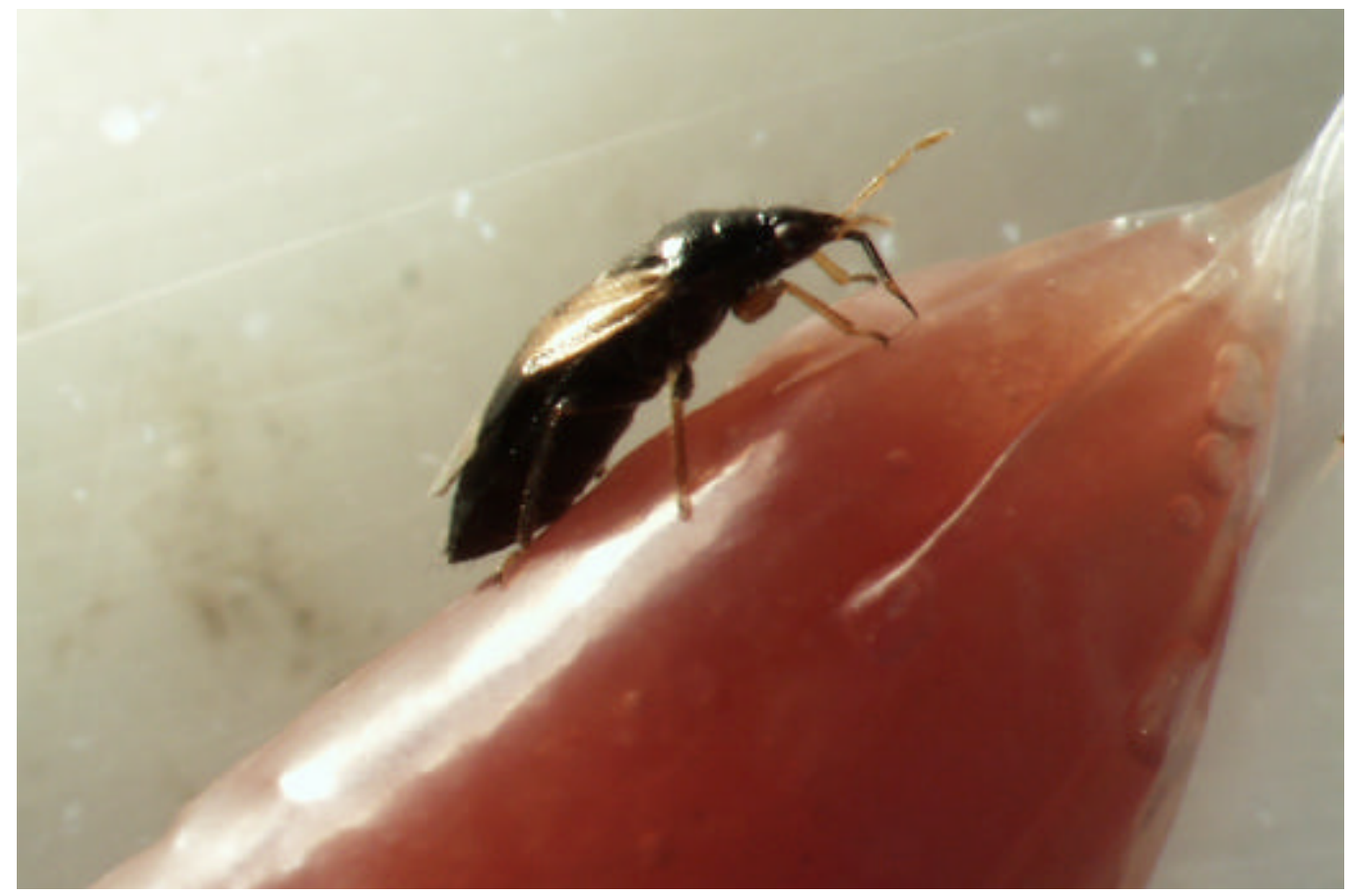

Figure 3. An adult of Orius laevigatus (Fieber) feeding on artificial diet (photo Y. Arijs). 


\section{Drawbacks of (Exotic) Generalist Predators}

Efficacy of Crop Protection. One of the major concerns of using nonspecific natural enemies in biocontrol programs is that they may interfere with the action of other beneficials present in the crop. Biocontrol agents may compete for the same prey, but they may also engage in trophic interaction with one another (i.e., intraguild predation). Particularly when preferred prey has become scarce, polyphagous predators may start attacking other beneficials. Intraguild predation among generalist predators has been documented to affect the success of biological control programs [see Rosenheim et al. (1995) for a review].

Facultative plant feeding by predators may be regarded as a negative feature if the predators risk injuring the crop. For instance, mirid bugs like M. caliginosus and Dicyphus spp. have been reported to cause damage by puncturing tomato fruits (Albajes \& Alomar 1999). However, occasional or even regular feeding on vegetative plant parts by these and other zoophytophagous heteropterans has not been found to inflict crop damage. Predators may also be exposed to systemic insecticides when feeding on plants. In glasshouse vegetables, it has been observed that systemic applications of imidacloprid for aphid control eradicated populations of the predatory pentatomid $P$. maculiventris (unpublished data). Compatibility of applications of systemic insecticides with releases of facultatively phytophagous predators should therefore be thoroughly assessed.

Environmental Concerns. Several workers have addressed the environmental risks associated with the use of non-native natural enemies in augmentative or, more often, classical biological control programs. Even when released in more or less closed ecosystems like glasshouses, it is very likely that some of the released natural enemies will disperse away from the crop environment. When imported biological control agents invade natural habitats, they may cause direct or indirect effects (van Lenteren 2001). Direct effects are related to the fact that nonspecific predators or parasitoids may attack nontarget components of the native fauna. Indirect effects are based on interactions through shared prey or hosts, or shared natural enemies, and may lead to perturbations at different trophic levels. There is particular concern that introduced beneficials that succeed in becoming established in their new environment, may displace closely related indigenous species. For instance, the introduction of the Eurasian lady beetle Coccinella septempunctata L. and of the Asian lady beetle $H$. axyridis into North America has been claimed to cause significant declines in populations of native coccinellid taxa (Howarth 2001). Some even fear that introductions of nonindigenous natural enemies for biological control may have already caused extinctions of target and nontarget organisms. However, there is some dispute as to the validity of the evidence brought forward to prove the harmful side-effects of biocontrol introductions (see van Lenteren 2001 and Howarth 2001 for conflicting views; see also Lynch et al. 2001 for an overview of the evidence). In short, despite the massive numbers of non-native natural enemies that have been released in classical and augmentative biological control programs, there is no unequivocal evidence that introduced arthropods have been the direct cause of species extinctions. But then, there is also no evidence that dramatic perturbations of natural ecosystems as a result of biocontrol introductions of arthropods have not occurred: severe impacts may have been overlooked because of a consistent lack of post-release studies.

There is a general agreement that there is a greater risk of environmental problems when the introduced natural enemies are generalists. Imported generalists may attack different nontarget organisms in native habitats and may consequently establish more easily and persist at higher densities than specialists (Lockwood et al. 2001).

\section{Assessing Environmental Risks of Exotic Generalist Predators}

A substantial part of the generalist predators used in augmentative biocontrol are nonindigenous and there is a justified concern that the use of exotic organisms may hold environmental risks. As a consequence, different countries have started regulating the importation of biological control agents (for details see van Lenteren 1997, 2001). The FAO has developed a Code of Conduct for the Import and Release of Exotic Biological Control Agents, which some countries have used as a basis for their risk assessment procedures. In the United States, the Plant Protection and Quarantine Division of the Animal and Plant Health Inspection Service (APHIS) issues permits for the introduction and interstate shipment of nonindigenous arthropod predators and parasitoids based on an Environmental Assessment. In Europe, several countries have developed regulations for the importation and release of nonindigenous beneficials, whereas others impose no restrictions whatsoever. Harmonization of legislation within the European Union framework is under discussion, with inputs from international bodies like the European and Mediterranean Plant Protection Organization (EPPO) and the Organization for Economic Co-operation and Development (OECD). Also in South America, regulation of the import and release of non-native biological control agents has been initiated. In Brazil, importation of exotic beneficial arthropods is subject to regulations developed by the Ministry of Agriculture (EMBRAPA website, http:// www.sede.embrapa.br).

In most cases, risk assessment procedures are largely based upon evaluations of host specificity. Evidently, this approach disfavors the importation of generalist natural enemies. We feel, however, that rejection of a non-native natural enemy intended for augmentative use solely based on its (assumed) broad host range may be unjustified. Basically, two questions need to be addressed: (1) what are the odds that an exotic natural enemy used in augmentative biological control will establish in natural ecosystems of the new region, and (2) what is the risk of a substantial impact on the populations of native taxa?

To find an answer to the first question, the adaptedness of the exotic natural enemy to the climatic conditions prevailing in the region of introduction is a first point of interest. Given the transient effect that is usually envisaged 
in augmentative biological control, the overwintering ability of a natural enemy is not a trait that is selected for (very unlike the situation in classical biological control). Many exotic natural enemies released in European greenhouses are unlikely to survive winter, but some may. For instance, a research program funded by the European Union established the lack of overwintering capability in the nearctic generalist predator Orius insidiosus (Say) in Italy, but indicated that the Asian lady beetle $H$. axyridis may successfully overwinter in that area (Lynch et al. 2001). Certainly, overwintering ability of an introduced species may depend upon the geographic origin of the strain used. But even when the beneficial originates from an area with similar climatic conditions and experiments suggest that it may overwinter, it is far from certain that the introduced natural enemy will establish. A nice illustration of this is the failure to introduce the spined soldier bug P. maculiventris in Europe for classical biological control of the Colorado potato beetle. From the 1930 s up to the 1970s numerous field releases were made in several European countries (e.g., France, Germany, Yugoslavia, Poland, Russia, Ukraine) using insects originating from Canada and the northern United States. Despite the ability of $P$. maculiventris to survive harsh winters in its area of origin and despite its broad host range, all attempts to establish the predator in Europe failed (see De Clercq 2000 for references). Another factor that may determine the ability of an introduced arthropod to establish and to build up sufficiently large populations to cause environmental damage is the presence of natural enemies in the area of introduction. The fact that the pentatomid predators $P$. maculiventris and $P$. bioculatus never became established in Europe may be related in part to heavy parasitization of eggs by native scelionid wasps (e.g., Trissolcus, Telenomus) (Buschman \& Whitcomb 1980, Jermy 1980). Another element to be considered is the dispersal ability of a non-native agent. Natural enemies with good dispersal abilities have a greater probability of invading nontarget habitats. High dispersal rate of an exotic biocontrol agent may, however, not always benefit establisment: Jermy (1980) attributed the failure of $P$. bioculatus to establish in Europe in part to the high tendency of the released adults to disperse, which limits the probability of mating and survival of small inoculative populations.

To predict the potential impact of an exotic natural enemy on native fauna, ideally both direct and indirect effects should be investigated. The assessment of nontarget effects in pre-release evaluations is, however, mainly focused on host range testing. Host (or prey) specificity screening can never cover all species at risk of being attacked because that would mean testing hundreds of possible host species (van Lenteren 2001). Further, it again deserves emphasis that the laboratory evaluation of host specificity may not always yield ecologically significant results. Laboratory experiments where arthropods are confined at unrealistic densities in small artificial arenas tend to overestimate the killing capacity of a predator and ignore avoidance behavior that may occur at a larger spatial scale. Learning behavior of a laboratory-reared natural enemy may influence its host acceptance patterns. Also, small-scale laboratory tests have limited capacity for predicting indirect nontarget effects (like the displacement of closely related native predators occupying similar niches). Habitat specificity of a predator may be just as important as prey specificity but is a criterion that cannot easily be evaluated in the laboratory. Specific microhabitat demands of a predator may lower its degree of polyphagy and make its use less risky for nontarget organisms. It would therefore be advisable to elaborate a sequential evaluation procedure, where field-realistic experiments validate results from laboratory trials (van Lenteren et al. 2002). Obviously, if such field trials are performed in the area of introduction, extreme care should be exerted that released exotics can be contained and do not disperse into natural habitats.

\section{Conclusions and Recommendations}

Generalist arthropod predators have important assets as biological control agents of crop pests, but also have their limitations. In a number of cropping systems, however, augmentative releases of indigenous and exotic generalist predators have yielded excellent pest control. More and more growers depend upon their use to keep damage below the economic injury level, allowing them to minimize inputs of chemical pesticides. Environmental problems associated with the use of exotic biocontrol agents can be minimized by accurately regulating their importation and release, not by simply calling for their abolishment. In a growing number of countries, registration procedures are being designed addressing the taxonomic identity, effectiveness, quality standards, and possible nontarget effects of commercially marketed beneficial arthropods. Registration demands should, however, be reasonable, so as not to hamper the implementation of biological control as a viable alternative to chemical control. Finally, it should be emphasized that many native natural enemies have received little attention as to their value for augmentative biological control. However, there is a growing awareness among researchers and suppliers of beneficials that an enormous potential is waiting here to be investigated.

\section{Acknowledgments}

I am grateful to Antônio R. Panizzi for inviting me to write this forum paper. Joop van Lenteren, Karel Bolckmans, Jake Blehm, and Fernando J. Tambasco are thanked for helpful suggestions and insights into the biological control situation in Europe and the Americas. Carl W. Schaefer is kindly acknowledged for reviewing an earlier version of the manuscript. Thanks go also to Yves Arijs, Pascal De Rop and Vincenzo Vacante for supplying photographic material.

\section{Literature Cited}

Albajes, R. \& O. Alomar. 1999. Current and potential use of polyphagous predators, p. 265-275. In R. Albajes, M. Lodovica Gullino, J.C. van Lenteren \& Y. Elad (eds.), Integrated pest and disease management in greenhouse crops. Kluwer Acad. Publ., Dordrecht, 545p. 
Anonymous. 2001. 2002 directory of least-toxic pest control products. IPM Pract. 23(11/12): 1-39.

Buschman, L.L. \& W.H. Whitcomb. 1980. Parasites of Nezara viridula (Hemiptera: Pentatomidae) and other Hemiptera in Florida. Fla. Entomol. 63: 154-162.

De Clercq, P. 2000. Predaceous stinkbugs (Pentatomidae: Asopinae), p. 737-789. In C.W. Schaefer \& A.R. Panizzi (eds.), Heteroptera of economic importance. CRC Press, Boca Raton, FL, 828p.

Dickens, J.C. 1999. Predator-prey interactions: olfactory adaptations of generalist and specialist predators. Agric. For. Entomol. 1: 47-54.

Driesche, R.G. van \& T.S. Bellows, Jr. 1996. Biological control. Chapman \& Hall, New York, 539p.

Gordh, G. \& D.H. Headrick. 2001. A dictionary of entomology. CABI Publ., CAB International, Wallingford, 1032p.

Howarth, F.G. 1991. Environmental impacts of classical biological control. Annu. Rev. Entomol. 36: 485-509.

Howarth, F.G. 2001. Environmental issues concerning the importation of nonindigenous biological control agents, p. 70-99. In J.A. Lockwood, F.G. Howarth \& M.F. Purcell (eds.), Balancing nature: assessing the impact of importing non-native biological control agents (An international perspective). Entomol. Soc. Am., Proc. Thomas Say Publ. Entomol., Lanham, MD, 130p.

Huffaker, C.B., F.J. Simmonds \& J.E. Laing. 1976. The theoretical and empirical basis of biological control, p. 41-78 In C.B. Huffaker \& P.S. Messenger (eds.), Theory and practice of biological control. Academic Press, New York, 788p.

Jermy, T. 1980. The introduction of Perillus bioculatus into Europe to control the Colorado beetle. OEPP/EPPO Bull. 10: 475-479.

Knight, H.H. 1923. Studies on the life history and biology of Perillus bioculatus Fabricius, including observations on the nature of the color pattern. 19th Rep. State Entomol. Minn.: 50-96.

Leftwich, A.W. 1976. A dictionary of entomology. Crane Russak, New York, 360p.

Legaspi, J.C. \& B.C. Legaspi Jr. 1998. Life-history tradeoffs in insects, with emphasis on Podisus maculiventris (Heteroptera: Pentatomidae), p. 71-87. In M. Coll \& J.R. Ruberson (eds.), Predatory Heteroptera: their ecology and use in biological control. Entomol. Soc. Am., Proc. Thomas Say Publ. Entomol., Lanham, MD, $233 p$.
Lenteren, J.C. van. 1997. Benefits and risks of introducing exotic macro-biological control agents into Europe. OEPP/EPPO Bull. 27: 15-27.

Lenteren, J.C. van. 2001. Harvesting safely from biodiversity: natural enemies as sustainable and environmentally friendly solutions for pest control, p. 15-30. In J.A. Lockwood, F.G. Howarth \& M.F. Purcell (eds.), Balancing nature: assessing the impact of importing non-native biological control agents (An international perspective). Entomol. Soc. Am., Proc. Thomas Say Publ. Entomol., Lanham, MD, 130p.

Lenteren, J.C. van, F. Bigler, G. Burgio, H.M.T. Hokkanen \& M.B. Thomas. 2002. Risks of importation and release of exotic biological control agents: how to determine host specificity? IOBC/WPRS Bull. 25: 281-284.

Lenteren, J.C. van \& J. Woets. 1988. Biological and integrated pest control in greenhouses. Annu. Rev. Entomol. 33: 239-269.

Leppla, N.C. \& E.G. King. 1997. The role of parasitoid and predator production in technology transfer of field crop biological control. Entomophaga 41: 343-360.

Lockwood, J.A., F.G. Howarth \& M.F. Purcell. 2001. Summary: common ground, great divides, and building bridges, p. 15-30. In J.A. Lockwood, F.G. Howarth \& M.F. Purcell (eds.), Balancing nature: assessing the impact of importing non-native biological control agents (An international perspective). Entomol. Soc. Am., Proc. Thomas Say Publ. Entomol., Lanham, MD, 130p.

Lynch, L.D., H.M.T. Hokkanen, D. Babendreier, F. Bigler, G. Burgio, Z.-H. Gao, S. Kuske, A. Loomans, I. Menzler-Hokkanen, M.B. Thomas, G. Tommasini, J.K. Waage, J.C. van Lenteren \& Q.-Q. Zeng. 2001. Insect biological control and non-target effects: a European perspective, p. 99-125. In E. Wajnberg, J.K. Scott \& P.C. Quimby (eds.), Evaluating indirect ecological effects of biological control. CABI Publ., CAB International, Wallingford, 288p.

Matthews, R.W. \& J.R. Matthews. 1978. Insect behavior. Wiley, New York, 507p.

McPherson, J.E. 1980. A list of prey species of Podisus maculiventris (Hemiptera: Pentatomidae). Great Lakes Entomol.13: 17-24.

Murdoch, W.W., J. Chesson \& P.L. Chesson. 1985. Biological control in theory and practice. Am. Nat. 125: 344-366.

Powell, W., M.P. Walton \& M.A. Jervis. 1996. Populations and communities, p. 223-292. In M. Jervis \& N. Kidd (eds.), Insect natural enemies. Practical approaches to their study and evaluation. Chapman \& Hall, London, 491p. 
Rosenheim, J.A., H.K. Kaya, L.E. Ehler, J.J. Marois \& B.A. Jaffee. 1995. Intraguild predation among biological-control agents: theory and evidence. Biol. Control 5: 303-335.

Saint-Cyr, J.-F. \& C. Cloutier. 1996. Prey preference by the stinkbug Perillus bioculatus, a predator of the Colorado potato beetle. Biol. Control 7: 251-258.

Schaefer, C.W. 1996. Bright bugs and bright beetles: asopine pentatomids (Hemiptera: Heteroptera) and their prey, p. 18-56. In O. Alomar \& R.N. Wiedenmann (eds.), Zoophytophagous Heteroptera: implications for life history and integrated pest management. Entomol. Soc. Am., Proc. Thomas Say Publ. Entomol., Lanham, MD, 202p.

Symondson, W.O.C., K.D. Sunderland \& M.H. Greenstone. 2002. Can generalist predators be effective biocontrol agents? Annu. Rev. Entomol. 47: 561-594.

Torre-Bueno, J.R. de la. 1937. A glossary of entomology. Brooklyn Entomol. Soc., New York, 336p.

Wiedenmann, R.N. \& J.W. Smith, Jr. 1997. Attributes of natural enemies in ephemeral crop habitats. Biol. Control 10: $16-22$. 